\title{
Towards International Legitimization of the Responsibility to Protect's Third Pillar
}

\author{
Arsalan Haji AlMizory \\ College of Law and Politics, Department of Law, Nawroz University, Kurdistan Region - Iraq
}

\begin{abstract}
Over the past few years, the question whether international law permits the use of force not in response to existing violence but to avert and prevent mass atrocity crimes occurring within the boundaries of a sovereign State has taken on added significant in the aftermath of the humanitarian tragedies of the 1990s. Responsibility to Protect (R2P) is a complicated and emerging norm of international law, which represents the start of a new era for the United Nations (UN), seeks to provide a means for the Security Council to take enforcement measures under Chapter VII to prevent mass atrocity crimes. The research discusses that when the Security Council is deadlock and peaceful measures have been exhausted, it is important to have a legal basis of using limited armed force as a last resort in the name of humanitarian intervention, to avert overwhelmingly atrocity crimes that a government has shown it is unwilling or unable to prevent. The research analyzes the case of Syria as a case study, which demonstrates that the presence of certain conditions enables the UN Security Council to implement R2P norm to save civilian populations from mass human rights violations.
\end{abstract}

Keywords: Mass Atrocity Crimes, The Use of Force, Humanitarian Intervention, Responsibility to Protect (R2P) Third Pillar

\section{Introductio}

In the aftermath of the humanitarian tragedies of the 1990s1, some scholars and commentators took the position that if no right of unilateral humanitarian intervention existed in international law, the law should be developed to respond to the terrible dilemma of human suffering amidst inaction on the part of the international community, and to establish such a right. 2 This controversial question to debate as to whether there was a duty on States to intervene in certain cases of humanitarian crisis caused by international crimes. Although, the protection of human rights featured as one of the United Nation's principal purposes, the UN Charter both generally prohibited the use of force and guaranteed a State's right to be free from intervention3, except for measures authorized by the Security Council under its Chapter VII powers or through State actions taken in self-defense.4 The Secretary-General's High-level Panel on Threats, Challenges and Change took a relatively cautious approach in its Report, A More Secure World: Our Shared Responsibility of December

Academic Journal of Nawroz University

(AJNU) Volume 8, No 3 (2019).

Received 1 March 2018;

Regular research paper : Published 27 June 2019

Corresponding author's e-mail : arsalanissa@gmail.com

Copyright @2018 Arsalan Haji AlMizory.

This is an open access article distributed under the

Creative Commons Attribution License.
20045, endorsed the 'emerging norm' that there is such a collective Responsibility to Protect in cases of genocide and other mass crimes and violation of international humanitarian law. Accordingly, the primary duty to protect lies with the State, but when a state fails to protect its own citizens the responsibility shifts to the international community if necessary as a last resort.

This article discusses the need for (a framework for non-UN authorized military force) when a state is unwilling or unable to fulfill its responsibility to protect its populations or is itself the actual perpetrator of atrocities. It argues that when peaceful measures have been exhausted and the Security Council is deadlocked, and a humanitarian crisis is at hand, it is important to have a legal basis of using limited armed force as a last resort in the name of humanitarian intervention. R2P's third pillar should allow the use of only low-level of force that fit within the UN Charter Chapter VII framework. In doing so, R2P, will be capable to fulfill its purpose of averting overwhelmingly atrocity crimes, that a government has shown it is unwilling or unable to prevent within its own borders, such as those witnessed in Rwanda, Kosovo, the agony in Darfur, and now in Syria Yemen and Myanmar. For the purpose, this article proceeds in three stages: the first seeks to clarify the notion of $\mathrm{R} 2 \mathrm{P}$ and the need for a legal framework. It identifies the notion of sovereignty and the debate about the legality of humanitarian intervention and unilateral 
military intervention and Chapter VII of the UN Charter. Later it set to apply R2P pillar three as a framework for non-UN authorized use of force for humanitarian crises.

\section{Background}

R2P arose on the heels of the UN's failures in Srebrenica and Rwanda in 1990s, and the international community's disagreement as to whether the UN Charter recognized a right of humanitarian intervention, in effect a right to use force to stem large-scale human rights crisis. It is worthy that the UN Charter prohibited the threat or use of force against the territorial integrity of any State, and preserved the principle of sovereignty and the 'inherent right' of self-defense to maintain international peace and security. Article 2 (4) introduces into international law the most farreaching limitation ever adopted on the use of force by States against one another:

"All Members shall refrain in their international relations from the threat or use of force against the territorial integrity or political independence of any state, or in any manner inconsistent with the purposes of the U.N."

This provision has long been recognized as stating a principle that has become part of customary international law and a rule of jus cogens, binding all States.6 Perhaps it sometimes seen as it states only a partial prohibition and that some instance of resource to force between States fall wholly outside its scope. However, commentators treat the provision as prohibiting all use of force, unless that use of force is justified by one of the limited exceptions provided for in international law.7 The Charter provides for two such exceptions: military action in self-defense, the right to which is preserved by Article 51, and military action authorized by the UN Security Council under the collective security provisions of Chapter VII of the Charter.

According to article 39 of Chapter VII, the Security Council must first determine the existence of any threat to the peace, breach of the peace, or act of aggression. Once that occurred, the Council may either make recommendations to those involved or decide what measures shall be taken, to maintain international peace and security. On the other hand, under article 41, the Security Council should first consider calling on UN Members to apply "measures not involving the use of armed force". Such measures include, inter alia, complete or partial interruption of economic relations and of rail, sea, postal, telegraph, and other means of communications, and the severance of diplomatic relations. However, if article 41 measures have been exhausted, or if the Council determines that it would be meaningless, under article
42 it may then "take such action by air, sea, or land forces as may be necessary to maintain or restore international peace and security. 8 In other words, the Security Council may authorize the use of force.

On the other hand, the tension between national sovereignty and international law has escalated in the past few years, about how far the international community could go to intervene in a sovereign State in the face of mass human rights violations. The intervention itself raises a complex set of questions relating to the use of force: under what conditions should the UN mandate force, and with what guidelines, or whether the Security Council had the authority to intervene in matters that were wholly within the borders of a State, or whether the international community could lawfully take action to prevent mass human rights violations. 9 In the past few years, sovereignty has become controversial, the term spurred both by growing sensitivity to human rights and by a reaction to atrocities perpetrated upon citizens by their own leaders. The term is increasingly defined, not as a license to control those within one's borders, but rather as a set of obligations towards citizens. 10 Accordingly, it is clear that the UN Charter generally prohibits the use of force except for measures authorized by the Security Council and renounces intervention in matters essentially within the domestic jurisdiction of Member States, unless issues of international peace and security are present.11 As such, the international community will be unable to stop mass human rights violations when the Security Council is deadlocked to authorize the use of force to avert overwhelming humanitarian catastrophe. This desperate situation led to the death of millions in Kosovo, Bosnia, Rwanda, and now in Syria, Yemen and Myanmar.

In consideration of the foregoing, debates surrounding the legality of humanitarian intervention under the auspices of the UN center around Article 2 (4) of the UN Charter, which is the legal basis for the UN prohibition against the use of force by states against other states. However, exceptions to this prohibition exists in situations where a state is using force as a means of self-defense under Article 51 of the UN Charter in response to armed attack, and when the Security Council authorized the use of force under its Chapter VII power to take measures to address "any threat to peace, breach of the peace, or act of aggression." On the other hand, on the side of the illegality of humanitarian intervention, it has been argued that the territorial integrity of a sovereign state is inviolate, as a long established precept on which the UN system is based, and that permitting exceptions even for humanitarian purposes would lead the international community down a slippery slope of 
each state policing every other state.12 Today, there no system to ensure that intervention for humanitarian purposes is consistently engaged, particularly in light of the inherent structure of the Security Council. The veto power of the five permanent members ensures, for example, that no humanitarian intervention under the UN could ever take place in Syria to end the mass human rights violations. Accordingly, it is true that, the conflict in Syria has proven that humanitarian intervention is seen to be ruled by the political interests of the powerful nations. Nonetheless, international legal scholars who support humanitarian intervention argued that when violations of human rights and humanitarian law reach outrageous levels, it is obligation of all states to take action to protect the victims. In this regard, Wolf argued that:

"[The argument against a right of humanitarian intervention is based primarily on an absolute interpretation of the article 2 (4) prohibition on the use of force and the fear of abusive invocation of the doctrine. The reality of current state practice, however, has rendered the absolute prohibition of the Charter meaningless. Thus, there exists a compelling need for a contemporary and realistic interpretation of article 2 (4) based on state practice that recognizes an exception to the Charter prohibition when force is required to prevent mass slaughter]".13

Thus, if an obligation to intervene occurred, it must be implemented consistently and must not be a mean by which the political motives of intervening states can be effectuated.14 On the other side, "unilateral humanitarian intervention" has faced numerous obstacles. Human rights were viewed as domestic matters and thus within the sovereign authority of states; intervention to vindicate these rights would be a violation of that sovereignty.15 In addition, prohibitions on the use of force and intervention, contained in the UN Charter, would seem to prescribe intervention and the use of force in most circumstances, including vindicating human rights. Thus, unilateral intervention has run into the legal roadblocks of non-intervention, sovereignty and prohibitions on the use of force.16The UN Charter on the other hand argues against allowing unilateral intervention on humanitarian ground. This limitation is found in Chapter VII of the UN Charter, which allows the Security Council to use force only upon a finding of a threat or breach of international peace and security or in response to an act of aggression. Therefore, it is argued that humanitarian crises must first poses a threat to international peace before Security Council action involving the use of force is permissible. However, the proponents of unilateral intervention on humanitarian ground, argued that unilateral intervention must be recognized as a legitimate option, primarily because "it remains doubtful whether collective intervention could be realistically expected to occur even in the face of egregious violations of human rights, if the major powers in the UN, especially those with veto power in the Security Council, did not find it in their national interest to authorize the use of force for such intervention".17 Thus, it can be concluded that humanitarian intervention has been evolved from a once widely disregarded policy into a compelling justification for the use of force to prevent mass human rights violations.18 However, the legal status of humanitarian intervention in international law remains controversial, scholars and State practice suggest that a strong argument can be made for the right's legality.

\section{The Emergence of Responsibility to Protect (R2P)}

\section{as a Response to Humanitarian Crises}

The catastrophic events of 1990's have led to a renewed reliance on the role of major states to keep order, and address humanitarian concerns within their traditional sphere of influence. Significantly, the war in Kosovo was a turning point in the international law of armed conflict. If proponents of the legal doctrine of humanitarian intervention have their way, Kosovo will stand as an example of a legitimate use of force for humanitarian ends.19 It is true that, the use of force against a sovereign state violates the general principles of international law. Considering whether international law recognizes humanitarian intervention, it is important to understand the legal and moral justifications for using force to prevent mass atrocity crimes. In this regard, former UN Secretary General Kofi Annan summarized the fundamental dilemma facing parties on either side of the debate: "On the one hand, is it legitimate for a regional organization to use force without a UN mandate? On the other, is it permissible to let gross and systematic violations of human rights, with grave humanitarian consequences, continue unchecked?"20 Thus, Malvina Halberstam puts the moral rationale for humanitarian intervention as "the right of people not to be killed should not depend on whether the State of which they are citizens is in a position to protect them, wants to protect them, or is itself the source of the danger".21 However, as the crises in Syria demonstrated the UN is not immune to the impediments of international geopolitics, often the competing interests of rival States make a Security Council action impossible.22 As such, it may be necessary for a State or organization to intervene unilaterally to prevent major human rights violations. 
Today, the threat or use of force without Security Council authorization has assumed importance, because of the Syria crisis, and the debate about a new strategic concept for the international community to counter breaches of massive human rights violations. In other words, a new norm should be developed to respond to the humanitarian tragedies amidst inaction on the part of the international community, and to establish such a right. In 2001, an independent Canadian-sponsored commission led to the establishment of an 'International Commission on Intervention and State Sovereignty' ICISS, which produced a report on the responsibility to protect, with the aim of finding a balance between the wish to respond effectively to humanitarian crises and the maintenance of a robust legal framework for such responses.23 The report confirmed that the concept of State sovereignty must entail a state's responsibility to protect its own citizens. However, the ICISS Report did not find widespread support for an unlimited view of sovereignty. Instead, the Super-Powers States agreed that sovereignty implies a dual responsibility: externally to respect the sovereignty of other States, and internally, to respect the dignity and basic human rights of all the people within the State.24 In other words, the ICISS emphasizes that the R2P exists essentially for protecting people and it is conceived of as the principal guardian of the rights of its people. However, "it loses this status of primacy in cases where it is unable or unwilling to ensure a protection; that it becomes the responsibility of the international community to act in its place". 25

In 2004, the High-level Panel on Threats, Challenges and Change set up by the UN Secretary-General took a relatively cautious approach in its Report, A More Secure World: Our Shared Responsibility.26 Consequently, R2P was put before States during the 60 anniversary of the United Nations in 2005, the General Assembly confirmed the traditional approach to the use of force for humanitarian purposes, subjecting it to Chapter VII powers of the Security Council and making no reference to a unilateral right of humanitarian intervention.27 The World Summit Document at paragraphs 138 and 139 recognized that States were prepared to take action to prevent mass atrocity crimes, genocide, crimes against humanity, war crimes, and ethnic cleansing on a "case-by-case basis".28 Thus, in its landmark Resolution 1674 on the Protection of Civilians in Armed Conflicts, the UN Security Council confirmed the main protection responsibilities of $\mathrm{R} 2 \mathrm{P}$, also reaffirming the Security Council's prerogative on the use of force. 29

Subsequently, in 2009, former UN Secretary-General Ban Ki Moon hailed this as a major achievement of the Summit. He presented a report (Secretary-General's
Report) clarifying R2P so that the international community could implement it in consistent manner. The report set out the three major pillars of R2P:

First, the responsibility of each State to provide security for their people and protect them from atrocity crimes;

Second, 'international assistance and capacity building for the State;

Third, when a State fails to provide the security and protect its population from mass crimes, the international community has the responsibility to react; this pillar included the possible use of force in accordance with the UN Charter. 'international assistance and capacity building for the State; 30

Having been endorsed by more than fifty States, 31 the three pillars approach has become widely accepted by the international community.

However, it is argued that the norm emerged from the World Summit in 2005 was inadequate because it did not provide clear guidance about the circumstances in which coercive military intervention might be justified in situation when the UN Security Council is deadlocked. In other words, the approach does not include a right of unilateral intervention in the absence of UN Security Council authority.

\section{R2P's Third Pillar and the case of Syria}

The weakness of collective humanitarian intervention is exemplified by the situation in Syria. Today, the international community may carry out international interventions for humanitarian reasons only. In other words, when a State is committing mass atrocity crimes against its own people, the international community must develop a set of criteria to discern and remedy such violations. Under R2P, limited and low-intensity use of force designed to protect populations that fit within the UN Charter Chapter VII. This use of force can only be used when peaceful options have been exhausted and the Security Council is unable to act. Accordingly, The International Commission on Intervention and State Sovereignty R2P Report states that:

["There is no better or more appropriate body than the United Nations Security Council to authorize military intervention for human protection purpose. The task is not to find alternative to the Security Council as a source of authority, but to make the Security Council work better than it has. Security Council authorization should in all cases be sought prior to any military intervention action being carried out. Those calling for an intervention should formally request such authorization, or have the Council raise the matter on its own initiative, or have the SecretaryGeneral raise it under Article 99 of the U.N. Charter. The Security Council should deal promptly with any 
request for authority to intervene where there are allegations of large scale loss of human life or ethnic cleansing. It should in this context seek adequate verification of facts or conditions on the group that might support a military intervention"].32

Accordingly, the legal justification rested upon the "R2P norm" that the force may be used in extreme circumstances to avoid humanitarian crisis. The use of force in such circumstances could be justified as an exceptional measure in support of purposes laid down by the UN Security Council, but without the Council's express authorization, when that is the only means to avert an overwhelming humanitarian catastrophe.33 In 1998, a Foreign and Commonwealth Office Minster was questioned on the legality of any future use of force. He answered that; the use of force could be justified on the grounds of overwhelming humanitarian necessity, without Security Council authority. He stated that:

"[There no general doctrine of humanitarian necessity in international law, but cases had arisen as in northern Iraq in 1991 where, in the light of all the circumstances, a limited use of force was justifiable in support of purposes laid down by the Security Council but without the Council's express authorization when that was the only means to avert an immediate and overwhelming humanitarian catastrophe. Such cases would in the nature of things be exceptional and would depend on an objective assessment of the factual circumstances at the time and the terms of relevant decisions of the Security Council bearing on the situation in question]".34

Thus, the use of force should be used only as a last resort to avert humanitarian crises that a government has shown it is unable or unwilling to prevent or is actively promoting, it rather should be proportionate and collective. In doing so, R2P providing a framework that regularizes the use of force to protect population from atrocity crimes. Only in exceptional circumstances $\mathrm{R}^{2} \mathrm{P}^{\prime} \mathrm{s}$ three-pillar framework ensures the international community will only use of force when completely necessary. According to the R2P's third pillar if a State has manifestly failed to protect its population, the international community should respond in a timely and decisive manner, through a "reasoned" calibrated and timely response, in accordance with the UN Charter.35

It is true that, during the past eight years of conflict in Syria, the Syrian civil population has been subjected to widespread and systematic attacks at the hands of the Syrian regime, "including aerial bombardment deliberately targeting civilians and civilian neighborhoods, including schools and hospitals, the use of prohibited weapons including chemical weapons, arbitrary arrest, imprisoned, torture and summary execution".36 However, the UN Security Council has unequivocally failed to prevent and then failed to respond. Repeatedly, Russia and China have vetoed against Security Council Resolutions on Syria that do not align with its political interests in tandem. According to the UN, as of April 2018, Russia used 12 negative vetoes on Security Council Resolutions for Syria.37 Accordingly, when the Security Council fails to act, a limited use of force should be allowed under R2P's third pillar to protect civilian populations from atrocity crimes. Thus, it is widely accepted by the international community that the general prohibition enunciated in Article 2 (4) of the UN Charter is part of jus cogens, which no derogation is ever permitted and which can be modified only by a subsequent norm of general international law having the same peremptory character. Hence, the fundamental rule from which any inquiry must proceed is Article 2 (4) of the Charter. At the same time, the prohibition of mass atrocity crimes is now accepted and recognized as jus cogens.38 In other words, in the face of mass atrocity crimes, the right of States to counter violations of human rights most likely becomes an obligation. To mitigate concerns regarding mass atrocity crimes and the use of force without Security Council authorization, R2P third pillar should only allow low intensity use of force under carefully limited circumstances. The Criteria that ensure this careful balance are as follows:

-A prima facie case must be established that atrocity crimes are occurring or about to occur. For the prima face case to be established, multiple international sources, such as international organizations or international body can provide an independent source of evidence. For example, The UN Human Rights Council (UNHRC), The International Committee for the Red Cross (ICRC) and the (ICC) office of the Prosecutor, can establish commissions of inquiry to determine the existence of mass atrocity crimes.39 According to a February 2018 UNHRC Report, Syrian government military forces have committed mass human rights violations against civilian populations, including aerial bombardment deliberately targeting civilians, the use of prohibited weapons including chemical weapons, arbitrary arrest, torture and murder.40 Most reports have concluded that possible mass atrocity crimes have committed by Syrian government since Syria's civil war began in 2011. In other words, the reports found that the government had deliberately targeted civilian populations and that they failed to destroy their chemical weapon stockpile, and then failed to protect its own people. Accordingly, the Syrian government has continuously been targeting civilian populations. In particular, there were signs of using numerous chemical 
weapons attacks on civilians and dropping thousands of barrel bombs on homes and civilians infrastructures since March 2011. Thus, the reliable documented proof have accused Al-Assad regime for mass atrocity crimes committed against civilian populations, and then a prima facie case is established.

- Peaceful options must be exhausted: this criterion corresponds to the last resort principle endorsed by ICISS for determining whether the use of force for humanitarian purposes is justifiable. These peaceful options include political sanctions, ceasefire, peace plans, and targeted economic sanctions.41 In Syria, the international community has tried multiply rounds of peace plans and sanctions without success. In 2012, the first peace talks launched by the United Nations in Geneva to discuss Assad's removal during a transition period, however, the US, Britain and France ignored Russian offer to have Syria's Assad step aside.42 Subsequently, on April 2012, the UN Security Council adopted Resolution 2042 authorizing advance team to monitor ceasefire. 43 Later, the Security Council passed Resolution 2043, which established the UN Supervision Mission in Syria (UNSMIS), and condemned the widespread violations of human rights committed by the Syrian regime. 44 In 2015, the Syrian government began consolidating their position with Iranian and Russian and Hezbollah backing. However, the UN brokered talks collapsed in 2017 when the Syrian regime delegation refused to discuss the constitutional process and presidential elections.45 Later, in 2017, The Astana peace process was launched, aimed at ending the Syrian conflict, but neither of the peace processes for Syria were successful because of refusal by Syrian regime.46 Thus, due to the failure of peaceful plans and escalating violence in the region, the international community imposed sanctions on Syrian regime in response to the massive human rights violations, and Assad's "violent repression" of civilians. These sanctions have been in force since December 2001, the sanctions include a blacklist of Syrian officials, an embargo on Syrian oil, investment restrictions and a freeze on Syrian central bank assets within the European Union.47 Accordingly, it is clear that all peaceful attempted to address the Syrian government's behavior have been ineffective and exhausted.

-The Security Council must unable to act in a timely or appropriate manner in response to humanitarian crises. It is true that, the UN Security Council has multiply been deadlocked on the matter of Syria. The first cast in October 2011 and February 2012, blocked resolutions that contained condemnatory statements and threatened sanctions against the Assad regime. In
July 2012, Russia and China vetoed resolution sponsored by the US, France and Germany that threatened sanctions on the Assad regime if it did not cease troop movements and the use of heavy weaponry in and around population areas.48 Later, in 2018, after the use of chemical weapons by the Syrian regime in Syria, the Security Council failed to adopt three resolutions that would have provided opportunities for fact-finding missions and future accountability due to Russian vetoes. A proposed draft Resolution would have established a new investigative mechanism, as well as identify those responsible for the use of chemical weapons. However, the draft received 12 votes in favor, two against (Bolivia and Russia) and one abstention (China).49 Accordingly, if these resolutions were adopted the situation in Syria would be different. Thus, it is true that the UN Security Council has failed the Syrian people, over half a million whom have been killed and over 5 million of whom are refugees, and 6.6 million of whom are internally displaced.50 As the violence continues to intensify, the Council has been unable to act in a timely and appropriate manner to address the Syrian regime's crimes against civilian populations.

-Military force must be limited to low-intensity options designed to protect populations. It is clear that, under R2P third pillar, armed force should be used only as a last resort to avert humanitarian crisis that a government has shown it is unable or unwilling to prevent. In other words, there should be no practicable alternative to the use of force to save lives; the use of force should be proportionate to the humanitarian purpose and likely to achieve its objectives; any use of force should be collective.51 In 1991, after the Gulf war, the US, UK, and France imposed the two non-fly zones over Iraq as a humanitarian effort to protect the Kurds in the north and the Shi'a Muslims in the south from repression. Although, the UN Security Council did not authorize the non-fly zones, and it did not authorize the use of force; this did not stop the US and the UK from claiming that their actions in the continuing clashes with Iraq over the non-fly zones were consistent with', supportive of', in implementation of 'pursuant' to Resolution 688.52 Consequently, the UK House of Commons acknowledged that:

"[The legal justification for the patrolling of the no-fly zones does not rest on the Security Council Resolution 688. That has not been the government's position. In terms of humanitarian justifications, we are entitled to patrol the no-fly zones to prevent a grave humanitarian crisis. That is the legal justification in international law. It does not on Resolution 688, 
although that resolution supports the position that we have adopted]".53

Respectively, in 1993, no-fly zones were a fixture during NATO operation in Bosnia and Herzegovina, and in 2011, the UN Security Council imposed it over Libya in a bid to protect civilians from air attack.54 In light of Syria's complex and precarious situation today, States have sometimes been willing to proclaim no-fly zones without the UN Security Council authorization, as the regime continues to kill civilians by using fighter jets and helicopter gunships. In addition, it is argued that 'humanitarian safe zones' are another low-intensity military option consistent with right intentions and proportionality criteria, which can be created even without a state's consent to protect civilian population from mass atrocity crimes.55 Rather, the recent US, UK and France strikes against Assad's chemical weapons were satisfy both the right intentions and proportionality standards proposed by the ICISS. The strikes were specifically associated with the Syrian regime chemical weapon program using low-intensity missiles to limit collateral damage.56

-A legitimate authority must authorize the use of lowintensity military force when the Security Council fails to act. The ICISS report demonstrated that legitimacy can be stemmed from authorities including neighboring States, regional organizations, coalitions of the willing, or multilateral operations, such as NATO's military intervention in Kosovo.57 Following the April 2018 chemical weapon attacks, the precision strikes on targets associated with the chemical weapon capabilities of Syrian regime were authorized by a 'legitimate authority' a collation of the US, UK, and France. The US President Trump said the strikes were in coordination with France and the United Kingdom, and the purpose of the campaign is to "establish a strong deterrent against the production, spread and use of chemical weapons." 58

-The sixth criterion is that the intervention must come at the request of credible opposition groups that represent victims of atrocity crimes. In the context of Syria, a request for low-intensity military operations could come from a consensus among several opposition groups and leaders including the Free Syrian Army (FSA), and the majority-Kurdish Syrian Democratic Forces (SDF). This criterion aims to ensure that the victims of atrocity crimes are requesting the military intervention and have the right intention behind their actions.59 In addition, in order to prevent abuse or misguided intentions, the use of force shall be done collectively through regional organizations, or coalition at willing, such as the EU, the African Union, NATO or the Arab League. In other words, the primary purpose of a request of military intervention must only be to avert or halt widespread violations of human rights. However, this condition is controversial as it may encourage the politicization of the conflict in Syria, and support the opposition groups against the lawful government and raise concerns of human rights violations. 60

- The seventh criteria require that the use of force should be followed up with or integrated into a larger strategy and policy for addressing humanitarian crises. This means that if military intervention action is taken because of a breakdown or abdication of a State's own capacity and authority in discharging its "R2P", there should be a genuine commitment from countries and/or regional originations to helping to build a durable peace, and promoting good governance and sustainable development, ensuring sustainable reconstruction and rehabilitation.61 In Syria, it is estimated that reconstruction would cost at least $\$ 250$ billion. 62 However, the EU and the US have maintained that they will not fund reconstruction in government-held Syria in the absence of a political transition along the lines of the UN Security Council resolution 2254.63

\section{Conclusion}

In 2005, the World leaders agreed that R2P does not countenance non-consensual military force without the UN Security Council authorization and does not set out criteria for the use of force beyond the mass atrocity crimes. Under the third pillar R2P, a broader responsibility falls on the international community when a State is unwilling or unable to fulfil its responsibility to protect. Over the past decade, the concept has made significant contributions to the protection of the civilian population from atrocity crimes. Unfortunately, the international community is constantly witnessing mass atrocity crimes as the direct consequence of the failure of States to take preemptive measures. The mass killings, rape, arson, amongst other mass atrocities committed against the Rohingya population of Myanmar, Syria, Darfur, Congo, Sri Lanka, and Yamen could have been prevented by proper implementation of the concept of the R2P. Today, R2P is morally accepted, but hard to enforce, as it remain uncertain from a normative point of view or lack support. The concept has been criticized in many ways for being a political catchword rather than a legal norm. However, by establishing specific criteria that allow for the use of limited use of force when the Security Council is deadlocked, R2P would become a new rule of customary international law and enforceable. 


\section{References}

\subsection{Books and Edited books}

1-Lowe V. and Tzanakopoulos A, Humanitarian Intervention (Max Planck Encyclopedia of Public International Law (Oxford University Press 2011).

2-UK Materials on International Law (69 British Year Book of International Law 1998).

\subsection{Journal Articles}

1-Annan K, 'Two Concepts of Sovereignty' (Economist) (18 September 1999) https://www.economist.com/international/1999/09 /16/two-concepts-of-sovereignty (Last visited 22 July 2019).

2-Bassiouni M. C, 'Searching for Peace and Achieving Justice: The Need for Accountability' (1996) 59 Law \& Conte P.

3-Borger J. and Inzaurralde B, 'West 'ignored Russian offer in 2012 to have Syria's Assad step aside' (The Guardian) (15 September 2015). Available at https:/ / www.theguardian.com/world/2015/sep/15 / west-ignored-russian-offer-in-2012-to-have-syriasassad-step-aside (Last visited 19 March 2019).

4-Cohen Z. and Liptak K, 'US, UK, and France launch Syria strikes targeting Assad's chemical weapons' (CNN Politics) (14 April 2018). Available at https://edition.cnn.com/2018/04/13/politics/trump -us-syria/index.html (Last visited 19 March 2019).

5-Greenwood C, 'International Law and the PreEmptive Use of Force: Afghanistan, Al-Qaida, and Iraq' (2003) 4 San Diego Int'1 L.J.

6-Gray C, 'From the Unity to Polarization: International Law and the Use of Force against Iraq' (2002) 13 EJIL.

7-Gordon R. E, 'Intervention by the United Nations: Iraq, Somalia, and Haiti' (1996) 31 Tex. Int'1 L.J.

8-Halberstam M, 'The Legality of Humanitarian Intervention' (1995) 3 Cardozo J. Int'1 \& Comp.L

9-'House of Commons Hansard', Debates, (26 February 2001). https:/ / publications.parliament.uk/pa/cm200001/c mhansrd/vo010226/debtext/10226-20.htm (Last visited 19 March 2019).

10-Merriam J. J, 'Kosovo and the Law of Humanitarian Intervention' (2001) 33 Case W. Res. J. Int'1 L.

11-Marcus M, 'Humanitarian Intervention without Borders: Belligerent Occupation or Colonization'? (2002) 25 Hous. J. Int'1 L.

12-Nada V. P, 'Tragedies in Somalia, Yugoslavia, Haiti, Rwanda and Liberia -Revisiting the Validity of Humanitarian Intervention Under International Law' (1998) 26 Denv. J. Int'1 L. \& Pol'y.
13-'Press Statement: GCIJ Files Article 15 Communication with ICC Prosecutor on Syria' (The Guernica Group) (March 2019) (London, Madrid \& San Francisco)

(https://www.guernicagroup.org/news/pressstatement-gcij-files-article-15-communication-withicc-prosecutor-onsyria?fbclid=IwAR0pGpploQfcueeOKi9qJa6fpLX3sQoMIuouHyL8Ct0ON2oj2L50keR63A (Last visited 18 March 2019).

14-Stahn C, 'Responsibility to Protect: Political Rhetoric or Emerging Legal Norm' (2007) 101 The Ame. J. Int'1 L.

15-Schmitt M. N, 'Preemptive Strategies in International Law' (2003) 24 Mich. J. Int'1 L.

16-Schachter O, 'International Law in Theory and Practice' (1991) Hereinafter Schachter International Law.

17-Wolf D, 'Humanitarian Intervention' (1998) 9 Mich. Y.B. Int'1 Leg. Stud.

18-Williams P. R, Ulbrick J. T and Worboys J, 'Preventing Mass Atrocity Crimes: The Responsibility to Protect and the Syria Crises' (2012) 45 Case Western Reserve J. Int'1 L.

19-(...) 'A brief history of peace attempts and failures in Syria' (TRT World) (27 October 2018). Available at https:/ / www.trtworld.com/mea/a-brief-history-ofpeace-attempts-and-failures-insyria21155/amp?fbclid=IwAR0hcI_9zRBL0SxbtPS4Ta kPKFF3FtQUM1KXY4v0drpdY1nZT4CGb0UQPnQ (Last visited 19 July 2019).

20-(...) 'Syria: the Astana peace process' (France 24) (5 Sep 2018). Available at https:/ / www.france24.com/en/20180905-syriaastana-peace-process (Last visited 19 July 2019).

21-(...), JNS.org, 'After eight years of civil war, the return of Syria to the Arab world' (The Israel Press) (12 March 2019). https://theisraelpress.com/middleeast/ after-eight-years-of-civil-war-the-return-of-syriato-the-arab-world/ (Last visited 20 July 2019).

22-(...) 'Syria Emergency' (UNHCR) (13 March 2019) https://www.unhcr.org/syria-emergency.html (Last visited 20 July 2019).

23-(...) 'Syria war: Lawyers submit first war crimes cases against Assad' (BBC News) (7 March 2019). Available at https://www.bbc.com/news/worldmiddle-east-47483714 (Last visited 20 July 2019).

24-(...), 'No-fly zones: The legal position' (BBC News) (19 February 2001). Available at http://news.bbc.co.uk/2/hi/middle_east/1175950.st m (Last visited 20 July 2019).

25-(...), 'Syria air strikes: US and allies attack 'chemical weapons sites' (BBC News) (14 April 2018). Available at https://www.bbc.com/news/worldmiddle-east-4376225 (Last visited 21 July 2019). 


\subsection{UN Documents/Reports}

1-General Assembly Resolution. Fifty-ninth session, UN Doc A/59/565 (2004) (24 December 2004).

2-Global Center for the Responsibility to Protect, Implementing the Responsibility to Protect: The 2009 General Assembly Debate: An Assessment (5, 6, August 2009).

3-'Human Rights Watch World Report on Syria' (2019). https://www.hrw.org/worldreport/2019/country-chapters/syria (Last visited 19 July 2019).

4-'International Commission on Intervention and State Sovereignty Responsibility to Protect: Report of the International Commission on Intervention and State Sovereignty' VII (2001) [hereinafter ICISS Report].

http://responsibilitytoprotect.org/ICISS\%20Report.p df. (Last visited 18 July 2019).

5-'No preconditions' accepted from Syrian parties, UN envoy says ahead of Geneva talks (UN News) (27 November 2017).

6-Parliamentary Hearing at the United Nations, New York, 20-21 (November 2008) Background Document: Session I.

7-'Report of the Independent International Commission of Inquiry on the Syrian Arab Republic', UN Doc. A/HRC/37/72, 26 February-23 March 2018. https://www.ohchr.org/Documents/HRBodies/HR Council/CoISyria/A-HRC-37-72_EN.pdf (Last visited 18 July 2019).

8-SC Res. 1674, (2008) UN Doc. S./RES/1674, 28 April 2008.

${ }^{8}$ For more details, see, Michael N. Schmitt, 'Preemptive Strategies in International Law' (2003) 24 Mich.J.Int'l L. 513.

9 The term "Humanitarian Intervention" referred to forcible interventions designed to stem large-scale human rights crises, such as the crisis in Rwanda, Srebrenica and Kosovo. For more details: See, Ruth E. Gordon, 'Intervention by the United Nations: Iraq, Somalia, and Haiti' (1996) 31 Tex. Int'1 L.J. 43.

${ }_{10}$ Former Secretary- General Kofi Annan spoke of the sovereignty of the "Individual as well as of the State". In addition, the concept also developed as "Responsibility", by the Special Adviser on the Prevention of Genocide Francis Deng. For more details see, Parliamentary Hearing at The United Nations New York, 20-21 November (2008), Background Document: Session I.

11 See, UN Doc. S/RES/917 (1994).

12 M Marcus, 'Humanitarian Intervention without Borders: Belligerent Occupation or Colonization?' (2002) 25 Hous. J. Int'1 L. 99.
9-SC Res. 2042 (2012) SC/10609, 14 April 2012.

10-SC Res. 2043 (2012) SC/10618, 21 April 2012.

11-SC Res 2254 (2015), SC/12171, 18 December 2015.

12-SC Res. 917, (1994) UN SCOR, S/Res/917 (1994).

13-Security Council fails to adopt three resolutions on chemical weapons use in Syria (UN News) (10 April 2018).

14-'Security Council Fails to Adopt Draft Resolution on Syria as Russian Federation, China Veto Text Supporting Arab League's Proposed Peace Plan', SC/10536, 4 February 2012.

15-Security Council Approves 'No-Fly Zone' over Libya, Authorizing 'All Necessary Measures' to Protect Civilians, by Vote of 10 in Favor with 5 Abstentions, SC/10200, 17 March 2011.

16-'Security Council -Veto List' http://www.un.org/depts/dhl/resguide/scact_veto _table_en.htm (Last visited 21 July 2019).

17-The Secretary-General's High-level Panel on Threats, Challenges and Change, A More Secure World: Our Shared Responsibility, 203, UN Doc. A/59/565, December 2004.

18-UN Secretary-General, Implementing the Responsibility to Protect. UN Doc A/63/677, 12 January 2009.

19-World Summit Outcome, GA Res. UN Doc A/RES/60/1 (2005), 24 October 2005.

\subsection{International Cases}

1-Military and Paramilitary Activities (Nicar. V. US), 1986 ICJ 14, 99-100 (June 27).

1 For example, Genocide in Rwanda in 1994 and genocide in Srebrenica in 1995.

2 See, V Lowe and A Tzanakopoulos, Humanitarian Intervention, (Max Planck Encyclopedia of Public

International Law OUP 2011).

${ }^{3}$ See, Charter of the United Nations, 26 June 1945, 1 UNTS XVI art. 1, 2 para $(3,4)$.

${ }^{4} \mathrm{Ibid}$, art. 2 para (7).

5 The Secretary-General's High-level Panel on Threats, Challenges and Change, A More Secure World: Our Shared Responsibility, 203, UN Doc. A/59/565, Dec 2004.

6 See, Military and Paramilitary Activities (Nicar. $V$. U.S.), 1986 ICJ 14, 99-100.

${ }^{7} \mathrm{C}$ Greenwood, 'International Law and the Pre-Emptive Use of Force: Afghanistan, Al-Qaida, and Iraq' (2003) 4 San Diego Int'1 L.J. 7. 
31 See, Global Center for the Responsibility to Protect, Implementing the Responsibility to Protect: The 2009 General Assembly Debate: An Assessment (5, 6, August 2009).

${ }^{32}$ See, ICISS Report, n (29).

33 For more details see, C. Gray, 'From the Unity to Polarization: International Law and the Use of Force against Iraq' (2002) 13 EJIL 1-19.

34 See,' UK Materials on International Law', 69 British Year Book of International Law (1998) 592-593.

35 See, 'Global Center for the Responsibility to Protect, Implementing the Responsibility to Protect', n (34).

36 For more details see, Press Statement: GCIJ Files Article 15 Communication with ICC Prosecutor on Syria, The Guernica Group, London, Madrid \& San Francisco (March 2019).

https://www.guernicagroup.org/news/pressstatement-gcij-files-article-15-communication-with-iccprosecutor-on-

syria?fbclid=IwAR0pGpploQfcueeOKi9qJa6fpLX3sQoMIuouHyL8Ct0ON2oj2L50keR63A (last visited 28 February 2019).

37 For more details, see, Security Council Veto List, http://www.un.org/depts/dhl/resguide/scact_veto_ta ble_en.htm (last visited 28 February 2019).

${ }^{38}$ For more details see, M. Cherif Bassiouni, 'Searching for Peace and Achieving Justice: The Need for Accountability', (1996) 59 Law \& Contemporary Problem 10-28.

https://scholarship.law.duke.edu/cgi/viewcontent.cgi? article $=1013 \&$ context $=$ lcp (last visited 28 February 2019).

${ }^{39}$ See, Williams, Ulbrick and Worboys, 'Preventing Mass Atrocity Crimes: The Responsibility to Protect and the Syria Crises', n (23).

40 For more details see, Report of the Independent International Commission of Inquiry on the Syrian Arab Republic, UN Doc. A/HRC/37/72, 26 February-23 March 2018. https:// www.ohchr.org/Documents/HRBodies/HRCo uncil/CoISyria/A-HRC-37-72_EN.pdf (last visited10 March 2019). See also, Human Rights Watch World Report on Syria 2019, https://www.hrw.org/worldreport/2019/country-chapters/syria (last visited 2 March 2019). See also, Syria war: Lawyers submit first war crimes cases against Assad, BBC News (7 March 2019) available at https://www.bbc.com/news/worldmiddle-east-47483714 (last visited10 March 2019). Also, Press Statement: GCIJ Files Article 15 'Communication with ICC Prosecutor on Syria', n (41).

${ }^{41}$ See, Williams, Ulbrick and Worboys, 'Preventing Mass Atrocity Crimes: The Responsibility to Protect and the Syria Crises', n (23).
13 See, D. Wolf, 'Humanitarian Intervention' (1998) 9 Mich. Y.B. Int'1 Leg. Stud. 333, 368.

${ }^{14}$ See, O. Schachter, 'International Law in Theory and Practice' (1991) Hereinafter Schachter International Law, 123-126.

${ }^{15}$ See, Gordon, 'Intervention by the United Nations: Iraq, Somalia, and Haiti' n (11).

16 Ibid.

17 See, Ved P. Nada, 'Tragedies in Somalia, Yugoslavia, Haiti, Rwanda and Liberia -Revisiting the Validity of Humanitarian Intervention Under International Law', Part II (1998) 26 Denv. J. Int'1 L. \& Pol'y 827-831.

18 For more details see, Paul R. Williams, J Trevor Ulbrick and J. Worboys, 'Preventing Mass Atrocity Crimes: The Responsibility to Protect and the Syria Crises', (2012) 45 Case Western Reserve J. Int'1 L. 479480 .

19 John J. Merriam, 'Kosovo and the Law of Humanitarian Intervention' (2001) 33 Case W. Res. J. Int'l L. 111.

20 See, Kofi Annan, 'Two Concepts of Sovereignty, Economist', (September 18, 1999) 49.

${ }^{21}$ See, M. Halberstam, 'The Legality of Humanitarian Intervention', (1995) 3 Cardozo J. Int'1 \& Comp. L. 1, 2.

22 See, Merriam, 'Kosovo and the Law of Humanitarian Intervention' (n 24) 115.

23 See, Lowe and Tzanakopoulos, Humanitarian intervention, $\mathrm{n}(2)$.

24 See, International Commission on Intervention and State Sovereignty Responsibility to Protect: Report of the International Commission on Intervention and State Sovereignty VII (2001) [hereinafter ICISS Report]. http://responsibilitytoprotect.org/ICISS\%20Report.pdf. (last visited 25 February 2019).

25 For more details see, C. Stahn, 'Responsibility to Protect: Political Rhetoric or Emerging Legal Norm', (2007) 101 The Am J Int'1 L. 99-120.

${ }^{26}$ See, UN Doc. A/59/565 (2004) paras 199-203.

27 UN Doc. A/RES/60/1 (2005) World Summit Outcome para 139, 24 October 2005. http://www.un.org/en/development/desa/population Lmigration/generalassembly/docs/globalcompact/A_ RES_60_1.pdf (last visited 26 February 2019).

28 Ibid.

29 See, SC Res. 1674, UN Doc. S./RES/1674 (2008). ("Reaffirming the provisions of paragraphs 138 and 139 of the 2005 World Summit Outcome Document regarding the responsibility to protect populations from genocide, war crimes, crimes against humanity and ethnic cleansing").

30 For more details see, UN Secretary-General, Implementing the Responsibility to Protect. UN Doc. A/63/677, January 122009. 
ansrd/vo010226/debtext/10226-20.htm (last visited15 March 2019). For more details see, Gray, 'From the Unity to Polarization: International Law and the Use of Force against Iraq', n (38).

54 See, Security Council Approves 'No-Fly Zone' over Libya, Authorizing 'All Necessary Measures' to Protect Civilians, by Vote of 10 in Favour with 5 Abstentions, SC/10200 (17 March 2011). https:// www.un.org/press/en/2011/sc10200.doc.htm (last visited15 March 2019).

55 See, Williams, Ulbrick and Worboys, 'Preventing Mass Atrocity Crimes: The Responsibility to Protect and the Syria Crises', n (23).

56 For more details see, Syria air strikes: US and allies attack 'chemical weapons sites' (BBC News) (14 April 2018). available at https://www.bbc.com/news/worldmiddle-east-43762251 (last visited16 March 2019).

${ }^{57}$ For more details see, Williams, Ulbrick and Worboys, 'Preventing Mass Atrocity Crimes: The Responsibility to Protect and the Syria Crises', n (23).

58 See, Z Cohen and K Liptak, 'US, UK, and France launch Syria strikes targeting Assad's chemical weapons' (CNN Politics) (14 April 2018). available at https://edition.cnn.com/2018/04/13/politics/trumpus-syria/index.html (last visited17 March 2019).

59 Williams, Ulbrick and Worboys, 'Preventing Mass Atrocity Crimes: The Responsibility to Protect and the Syria Crises', n (23).

${ }^{60}$ For more details see, Human Rights Watch World Report on Syria (2019). https://www.hrw.org/worldreport/2019/country-chapters/syria (last visited 21 June 2019).

${ }^{61}$ For more details see, 'ICISS Report', n (29).

62 See, 'No preconditions' accepted from Syrian parties, UN envoy says ahead of Geneva talks (UN News) (27 November 2017). available at https://news.un.org/en/story/2017/11/637402-nopreconditions-accepted-syrian-parties-un-envoy-saysahead-geneva-talks (last visited18 March 2019).

63 See, Human Rights Watch World Report on Syria (2019), n (60). See also, Security Council Resolution 2254 (2015), Endorsing Road Map for Peace Process in Syria, Setting Timetable for Talks, SC/12171 (18 December 2015).

https://www.un.org/press/en/2015/sc12171.doc.htm (last visited18 March 2019).
42 See, J Borger and B Inzaurralde, 'West 'ignored Russian offer in 2012 to have Syria's Assad step aside', The Guardian (15 September 2015). available at https://www.theguardian.com/world/2015/sep/15/w est-ignored-russian-offer-in-2012-to-have-syrias-assadstep-aside (last visited 11 March 2019).

43 See, SC Res. 2042 (2012) SC/10609, 14 April 2012. https://www.un.org/press/en/2012/sc10609.doc.htm (last visited 12 March 2019).

44 See, SC Rec. 2043 (2012) SC/10618, 21 April 2012. https://www.un.org/press/en/2012/sc10618.doc.htm

(last visited 12 March 2019).

${ }^{45}$ See, 'A brief history of peace attempts and failures in Syria' (TRT World) (27 October 2018). available at https://www.trtworld.com/mea/a-brief-history-of-

peace-attempts-and-failures-in-syria-

21155/amp?fbclid=IwAR0hcI_9zRBL0SxbtPS4TakPKFF3 FtQUM1KXY4v0drpdY1nZT4CGb0UQPnQ (last visited12 March 2019).

46 See,' Syria: the Astana peace process' (France 24) (5 September 2018). available at https://www.france24.com/en/20180905-syria-astanapeace-process (last visited 13 March 2019).

47 For more details, see, (JNS.org) 'After eight years of civil war, the return of Syria to the Arab world' (The Israel Press) (12 March 2019). available at https://theisraelpress.com/middle-east/after-eightyears-of-civil-war-the-return-of-syria-to-the-arab-world/ (last visited 13 March 2019).

${ }^{48}$ See, Security Council Fails to Adopt Draft Resolution on Syria as Russian Federation, China Veto Text Supporting Arab League's Proposed Peace Plan, SC/10536 (4 February 2012). https://www.un.org/press/en/2012/sc10536.doc.htm (last visited 14 March 2019).

${ }^{49}$ For more details see, Security Council fails to adopt three resolutions on chemical weapons use in Syria (UN News) (10 April 2018). https://news.un.org/en/story/2018/04/1006991 (last visited14 March 2019).

50 See, Syria Emergency (UNHCR). (13 March 2019) https://www.unhcr.org/syria-emergency.html (last visited 14 March 2019).

51 For more details see, Gray, 'From the Unity to Polarization: International Law and the Use of Force against Iraq', n (38).

52 Ibid. For more details, see, 'No-fly zones: The legal position' (BBC News) (19 February 2001). available at http://news.bbc.co.uk/2/hi/middle_east/1175950.stm (last visited15 March 2019).

53 See, 'House of Commons Hansard', Debates, (26 February 2001). https://publications.parliament.uk/pa/cm200001/cmh 